\title{
A review on the quantification of soil water balance components as a basis for agricultural water management with a focus on weighing lysimeters and soil water sensors
}

\author{
Ein Überblick über die Ermittlung von Wasserhaushaltsgrößen als \\ Basis für die landeskulturelle Wasserwirtschaft mit Fokus auf Lysimeter \\ und Bodenwassersensoren
}

\author{
Reinhard Nolz ${ }^{1}$
}

\begin{abstract}
${ }^{1}$ Institute of Hydraulics and Rural Water Management; Department of Water, Atmosphere and Environment; University of Natural Resources and Life Sciences, Vienna (BOKU); Muthgasse 18, 1190 Wien, Austria; e-mail: reinhard.nolz@boku.ac.at
\end{abstract}

Received: 6 June 2016, received in revised form: 18 July 2016, accepted: 28 July 2016

\begin{abstract}
Summary
Knowing the components of a soil water balance—-for example, evapotranspiration, soil water content, and precipitation—is the basis for agricultural water management. Weighing lysimeters and soil water sensors are commonly used to quantify these components. Data can be used to validate common models to estimate evapotranspiration based on meteorological data, for instance. As every measurement device has its own characteristics, it is helpful to assess and improve the performance of a system to obtain best possible data. Recent developments in the processing of lysimeter data allow determining both evapotranspiration and precipitation directly from lysimeter data. Resulting datasets are characterized by a proper accuracy, completeness, and a high temporal resolution. Soil water sensors usually measure a physical property that is related to soil water content or matric potential via a specific calibration function. Hence, measurement accuracy depends not only on this calibration but also on basic physical principles and material properties. Knowing the performance of a device is, therefore, essential for the selection of an adequate sensor arrangement and truthful data interpretation. Advanced soil water monitoring sites combine different sensor types that are integrated into a wireless network to enable real-time data availability and provide a basis for large-scale monitoring.
\end{abstract}

Keywords: measuring system, evapotranspiration, water content, matric potential, data management

\section{Zusammenfassung}

Die Kenntnis von Bodenwasserhaushaltskomponenten - zum Beispiel Verdunstung, Bodenwasseranteil und Niederschlag - ist die Basis für landeskulturelle Wasserwirtschaft. Zur Bestimmung dieser Größen werden üblicherweise wägbare Lysimeter und Bodenwassersensoren herangezogen. Die Daten können verwendet werden, um Verdunstungsformeln zu evaluieren, welche zur Abschätzung der Verdunstung basierend auf meteorologischen Daten dienen. Da jedes Messgerät gewisse Eigenschaften aufweist, sollten diese ermittelt, beurteilt und gegebenenfalls verbessert werden, um bestmögliche Daten zu erhalten. Aktuelle Entwicklungen in der Aufbereitung von Lysimeterdaten ermöglichen die Ermittlung sowohl von Verdunstung als auch Niederschlag direkt aus Lysimeterdaten. Die daraus resultierenden Datensätze zeichnen sich durch hohe Genauigkeit, Vollständigkeit und hohe zeitliche Auflösung aus. Bodenwassersensoren messen üblicherweise eine physikalische Eigenschaft, die über eine Kalibrierfunktion mit einer physikalischen Bezugsgröße wie Bodenwasseranteil oder Matrixpotenzial in Beziehung gesetzt wird. Die Messgenauigkeit hängt somit von der Kalibrierung, aber auch von physikalischen Grundlagen und Materialeigenschaften ab. Die Kenntnis der Eigenschaften von Messgeräten ist für die Auswahl eines entsprechenden Messsystems sowie für eine bestmögliche Interpretation der Daten erforderlich. Moderne Messstellen für Bodenwassermonitoring stellen eine Kombination von mehreren Sensortypen dar. Die Sensoren sind üblicherweise in ein Fernmessnetz eingebunden, um die Datenübertragung in Echtzeit zu ermöglichen. Messnetze bieten zudem Informationen über größere Flächen.

Schlagworte: Messsystem, Verdunstung, Wasseranteil, Matrixpotenzial, Datenmanagement 


\section{Background and objectives}

Water is vital for humans, animals, and plants. Driven by various processes, it is continuously transported above, on, and below the surface of the earth. Soil represents only a thin layer between the earth's rocky crust and the atmosphere, but it is extremely important for vegetation as it provides anchorage to roots and stores water and nutrients. Soil water-as a part of the hydrological cycle-comprises water of the vadose zone, which is the zone between the land surface and the top of the phreatic surface. Plants absorb soil water through their root system and transport it to the atmosphere. A small amount is required for the process of photosynthesis, which combines water with carbon dioxide and solar energy from the atmosphere and converts them to carbohydrates. In this context, the availability of (soil) water and the interactions between soil, plant, and atmosphere are essential for nearly all life on earth.

Agricultural production (thus food security) strongly depends on environmental conditions, which build the framework for processes in the soil-plant-atmosphere continuum. While some environments provide favorable conditions for farming, others are less suitable. Already during the Neolithic Revolution, when societies changed from hunting and gathering to arable farming and livestock breeding, people started to modify their natural environment fundamentally in order to enhance food production (Bocquet-Appel, 2011). Conventional measures to achieve this objective have been-and still are-deforestation, soil cultivation, cultivar selection, plant breeding, and irrigation. By learning how to care for the soil and the thriving and prospering of plants, people enhanced agricultural management in the course of the millennia. In Europe, the development of advanced methods and techniques led to closed greenhouse systems with total control of the environment (Opdam et al., 2005). However, in the EU member states, all-season greenhouses production of fruits and vegetables is only complementing the dominating open-air production of a wide range and variety of crops (EUROSTAT, 2015). Consequently, most farmers have to face chancing environmental conditions, and they have to adapt their management strategies accordingly. In this regard, soil water management has always been a great challenge.

Loiskandl and Kammerer (2011) defined soil water management as "active involvement in controlling soil water content at an optimal state for all given purposes, including environmental needs." With regard to agricultural production, soil water status should remain within a certain range that is optimal for plant water uptake. If the soil becomes too dry, water-deficit stress is supposed to occur. In such a case, irrigation can help avoiding the reduction of both yield and quality. However, irrigation has to be adapted to soil properties in order to minimize potential negative environmental impacts such as deep percolation, leaching of water-soluble nutrients, water logging, and soil salinization. In certain circumstances, drainage - the counterpart of irrigation-is also required to keep the soil water content at an optimal state. Accordingly, the optimal state can be "a compromise between competing uses and needs to account for long-term sustainability of the soil water system" (Loiskandl and Kammerer, 2011).

Beside the immediate adaptation of agricultural management practices to local environments, global change will generate new challenges for farmers in future. Climate change, for example, will affect rainfall, temperature, and evapotranspiration. In many European regions, the predicted larger variability of environmental factors-for example, more frequent extreme events and longer drought periods - will increase the pressure on farmers to implement water-conserving practices and improve irrigation management (Olesen and Bindi, 2002). Furthermore, certain awareness is necessary in order to avoid undesired side effects-for example, soil salinization as a consequence of deficit irrigation strategies (Aragüés et al., 2015). Against this background, studying the soil water balance and its components is supposed to provide a basis for the development and assessment of approaches for agricultural water management.

This article focuses on the determination of water balance components by means of weighing lysimeters and soil water sensors. Regarding an adequate data interpretation, it is essential to consider both strengths and limitations of measurement systems and preferably reduce shortcomings. Therefore, system performance is particularly addressed in terms of measurement accuracy, precision, temporal resolution, and data management. Practical examples of recent developments are given concerning this matter. Reliable measurements can help understanding processes or directly serve as basis for management decisions. Examples of irrigation scheduling based on soil water monitoring are mentioned in the article. As weighing lysimeters and soil water sensors represent only point measurements, further efforts might become necessary to obtain large-scale information. Lysimeter data, for instance, were traditionally used to develop, calibrate, and validate models for the estimation of water balance components. Data of point-scale 
sensors and sensor networks are also used to calibrate and validate large-scale soil moisture monitoring techniques, which have advanced in recent years. Thus, the article also contains examples referring to this.

\section{Soil water balance}

\subsection{Relevant components of the soil water balance}

Soil consists of solids and a pore system that enables transport and storage of water. Soil water status can range from wet to dry, indicating the degree of saturation of the voids (Hillel, 1998). It can be described either by soil water content (volume of water per volume of soil) or by soil water potential (energy state of water at a certain point in relation to a reference level). Both quantities are linked via a soil-specific water retention function. Together with the relationship between matric potential and hydraulic conductivity, a water retention function characterizes the hydraulic properties of a soil (Hillel, 1998). Considering a certain volume of soil, inflow and outflow change its water content $(\Delta W)$. Under natural conditions, the main fluxes arise from evapotranspiration $(E T)$, precipitation $(P)$, deep percolation $(D P)$, and capillary rise $(C R)$.

Evapotranspiration represents fluxes of water (vapor) from the soil to the atmosphere as a combination of two subprocesses: evaporation and transpiration. While evaporation describes the process of vaporization-where water changes its phase from liquid to gaseous — from bare soil or a water surface, transpiration is associated with plant water uptake in the rooting zone (Monteith and Unsworth, 2013). Plants raise the water through their vascular tissues onto the stomata of the leaves from where it can vaporize. The main driving force originates from the potential gradient between the energy state of water in the (relatively wet) soil and the (relatively dry) atmosphere (Hillel, 1998). Hence, evapotranspiration is a continuous process-at least as long as soil water is available-that depends on atmospheric factors such as solar radiation, air temperature, air humidity, and wind velocity as well as on crop characteristics (Monteith and Unsworth, 2013).

Precipitation in its various forms (e.g., rainfall, hail, or snow) occurs when water condenses in the atmosphere and falls to the ground because of gravitation. Hence, it represents atmospheric inputs of water into the soil. In contrast to evapotranspiration, precipitation occurs occasionally.

Deep percolation is the movement of water out of the rooting zone and toward groundwater, whereas capillary rise acts in the opposite direction. Soil water studies often disregard capillary rise as it appears only at locations with a high groundwater table and flow rates are typically small. For flat areas with low groundwater table, Eq. 1 represents a simple water balance of the relevant components mentioned earlier in this section and irrigation $(I)$.

$$
E T=P+I-D P \pm \Delta W
$$

With regard to agricultural water management, evapotranspiration is a key component of the water balance. Together with precipitation as its "opponent," it describes representatively the climate of a region. Both quantities also provide the basis for water balance models, which may serve as decision support systems for irrigation management. Knowing the water balance of a specific area can thus be a meaningful step toward an economic and ecological agriculture.

\subsection{Quantifying soil water balance components}

Considering the components in Eq. 1, it is comparatively simple to measure $P$ (and $I$ ) by means of a rain gauge. The result is a volume of water that was collected within a certain time interval and is related to a certain surface area. In contrast, determination of $E T$ requires complex measurement systems.

Lysimeters separate a certain volume of soil from its surroundings in order to prevent lateral fluxes, and enable measurements of water and solute fluxes across its upper and lower boundary. Equipped with a weighing device to detect water content changes $(\Delta W)$ - the mass of the container and the solid soil remain the same-and devices to measure precipitation $(P)$ and drainage at the bottom $(D P)$ (e.g., tipping buckets), ET can be calculated according to Eq. 1 (Aboukhaled et al., 1982). State-of-the-art lysimeters are equipped with sensor arrays that measure soil parameters inside and outside of the lysimeter container to monitor and control boundary conditions similar to that of the undisturbed soil environment (von Unold and Fank, 2008). Hence, modern lysimeters are powerful tools to quantify water balance components with a high precision $(<0.1 \mathrm{~mm})$ and a high temporal resolution $(<10 \mathrm{~min})$ (Hannes et al., 2015).

Another method to determine ET relies on observing the change of water $(\Delta W)$ in a soil profile over time to solve Eq. 1. For this purpose, soil water content is traditionally determined by means of soil sampling and gravimetric 
analyses. In the past decades, sensor technologies largely replaced this method, because soil water sensors enable monitoring of water content at short time intervals without destructive and laborious soil sampling (Allen et al., 2011). However, a major potential source of error in the water balance method is the uncertainty in drainage and other undetected fluxes in and out of the control volume. Therefore, an advanced sensor arrangement should provide the possibility to obtain information about both the occurrence and the movement of soil water. Discovering fluxes requires measurement of the matric potential at different locations. According to the concept of soil water potential, water will flow from the higher energy level to the lower one (Hillel, 1998). A sensor setup that combines water content and matric potential measurements in different depths of a soil profile can, therefore, handle the tasks of a traditional lysimeter. The basic concept of such a "virtual lysimeter" considers that soil parameters always depend on natural conditions. Therefore, sensing an undisturbed part of soil not separated from the surrounding area better represents natural conditions (Kastanek et al., 2002). On the other hand, the capability of a site for monitoring soil water depends on the arrangement and the performance of the implemented sensors and sensor types, which can cause systemic weaknesses.

Lysimeter facilities generally provide accurate water balance data, but they do have some disadvantages compared with other techniques. Above all, they are not widely distributed because of their quite costly and complex construction, maintenance, and operation (Allen et al., 2011). Furthermore, the footprint of a lysimeter is small, so the measurements may not be representative of a larger area for several reasons, including differences in plant stand, tillage, moisture, fertilization, herbicide application, and simple random variability (Evett et al., 2016). The combination of lysimeter measurements and soil water monitoring in the field promises more comprehensive information, but these methods still represent only point-scale measurements. To obtain water balance components on a larger scale, one might use systems that require the application of relatively complex physical principles and techniques, such as Bowen ratio-energy balance, eddy covariance, and scintillometers (Allen et al., 2011). Furthermore, recent developments in large-scale soil moisture monitoring-including satellite data and global soil moisture networks, for instance-reveal opportunities to advance science and practice in this regard (Albergel et al., 2012; Ochsner et al., 2013). According to recent literature, irrigation wa- ter management is more and more considering remotely sensed data, partly in combination with model approaches, in order to obtain spatial information (e.g., Guermazi et al., 2016; Toureiro et al., 2016). Data of lysimeters and soil water sensors are typically used to calibrate and validate such combined approaches (e.g., Zhang and Wegehenkel, 2006).

Disregarding these novel developments, lysimeter data are traditionally used to develop, calibrate, and validate models to better understand the basic hydrological processes and make them applicable at a larger scale. Evapotranspiration, for instance, can be estimated using weather data and algorithms that describe surface energy and aerodynamic characteristics of the vegetation (Allen et al., 2011). A well-known model in this regard is the one after Penman and Monteith (PM), which was recommended as standard model for calculating reference evapotranspiration $\left(E T_{\text {ref }}\right)$ and subsequently plant water requirements by the Food and Agriculture Organization of the United Nations (FAO) (Allen et al., 1998). Several water balance models refer to this approach, for example, the FAO AquaCrop model (Heng et al., 2009). AquaCrop or similar models are often used as decision support for irrigation scheduling (e.g., Garcia-Vila and Fereres, 2011; Geerts et al., 2010; Montoya et al., 2015). Although models represent only a simplification of natural processes, they are easily available and users can simulate different (future) scenarios by modifying the input data or the model parameters. Consequently, model results often serve as basis for adaptations of management practices and political decisions.

The presented approaches and combinations of them offer plenty of opportunities to enhance agricultural water management in terms of irrigation, drainage, fertilization practices, and land management, for instance. In this regard, lysimeters and soil water sensors can deliver the essential database.

\subsection{Data acquisition and data management}

Observations of environmental processes and measurements are the basis for natural sciences. Research questions associated with agricultural water management or related topics focus on observations of soil water status, atmospheric processes (weather), and plant water status, for instance. In this regard, a measurement can be defined as "a process of experimentally obtaining one or more quantity values that can reasonably be attributed to a quantity," in which a quantity is "a property of a phenomenon, body, 
or substance, where the property has a magnitude that can be expressed as a number and a reference." Furthermore, a sensor is "an element of a measuring system that is directly affected by a phenomenon, body, or substance carrying a quantity to be measured" (JCGM, 2012). A measurement system typically contains several devices (e.g., weather instruments, soil water sensors, load cells) to measure different physical quantities. Electronic devices typically measure voltage, resistance, or frequency and then convert the values to physical quantities - for example, temperature, relative humidity, soil water content, or mass. For this purpose, some devices contain a basic calibration function, while others require a user calibration to obtain accurate data. Many soil water content sensors, for instance, detect the permittivity of the soil-water-air-composite within a sensed area, and specific calibration functions provide the relationship to transfer the sensor readings to water content values.

In general, every measurement system has weaknesses. Therefore, knowing the characteristics of single devices or a complete measurement system is essential for the selection of adequate devices, professional installation and application, and correct data interpretation. The performance of a sensor or a measurement system can be characterized by precision, accuracy, measurement range, reaction time, temperature effects, and others. In this context, precision is defined as "closeness of agreement between measured quantity values obtained by replicate measurements on the same or similar objects under specified conditions" and accuracy as "closeness of agreement between a measured quantity value and a true quantity value of a quantity to be measured" (JCGM, 2012).

Furthermore, an adequate data management is essential to obtain high-quality datasets. In this context, data management includes data acquisition, storage and backup, data processing, quality control, and calibration.

\section{Weighing lysimeters}

\subsection{Weighing and data processing}

The core part of a lysimeter facility is its weighing system. The challenge is to scale a large mass of several tons in order to measure differences of a few hundred grams. Lever-armcounterbalance systems - which were state of the art in the 1970s and 1980s - reduced the weighing mass to a fractional amount. This enabled measuring mass changes with satisfying accuracy (Aboukhaled et al., 1982). However, the weighing mechanism (alike every measurement system) is prone to both random and systematic errors. Disadvantageous are mainly oversensitivity to external disturbances, for example, such as exerted by wind (Howell et al., 1995; Malone et al., 1999; Nolz et al., 2009). In spite of the shortcomings, lysimeters with lever-arm weighing systems are still useful for current research tasks (e.g., Evett et al., 2015; Knappe et al., 2002; Knoblauch and Swaton, 2007; Wegehenkel et al., 2008). Therefore, updating older facilities-in particular with respect to accuracy and temporal resolution of lysimeter data-is a prerequisite to meet requirements of recent and future research tasks. Modernization should include the renewing of technical parts as well as the improvement of data management (Nolz et al., 2011). Nolz et al. (2013a) analyzed how wind flow affected the weighing accuracy of an old lysimeter facility. They found a characteristic oscillation behavior of the lever-arm system that was influenced by irregular wind forces. At 10-m-wind velocities larger than $5 \mathrm{~m} \cdot \mathrm{s}^{-1}$, the accuracy decreased considerably, but because of the irregular oscillation, the relation could not be described mathematically.

Beyond recommendations regarding optimization of the measurement procedure, improvements in data processing are necessary. Vaughan and Ayars (2009), for instance, published well-adjusted averaging procedures as an option for noise reduction arising from mechanical oscillation of a weighing system. Nolz et al. (2013b) tested two types of smoothing functions on a set of noisy lysimeter weighing data with respect to improved data interpretation: A basic piecewise sigmoid function was easy to fit and gave proper results of typical diurnal variation of evapotranspiration on single days without rainfall. However, during a longer period including rainfall events, a polynomial spline function performed better. Marek et al. (2014) used a moving average and Savitzky-Golay filtering to reduce errors in weighing lysimeter evapotranspiration. The advantage of continuous datasets is that they allow determining both $E T$ and $P$ directly from weighing data (Nolz et al., 2013b). Consequently, an objective (preferably automatized) data processing is of particular relevance when processing and comparing data from several lysimeter stations. In the past decade, the utilization of sophisticated lysimeters for water balance and climate change studies considerably increased (e.g., Balykin et al., 2016; Prasuhn et al., 2009; Zacharias et al., 2011). Hence, recent studies addressed the necessity to improve data processing also of modern lysimeter facilities (Hannes et al., 2015; Peters et al., 2014; Schrader et al., 2013). Peters et al. (2014), for instance, introduced a 
novel routine that uses adaptive filter parameters dependent on signal strength and noise (AWAT, adaptive window and adaptive threshold filter). Such and similar routines provide the basis for recently published lysimeter studies (e.g., Gebler et al., 2015; Rodný et al., 2016).

\subsection{Measurements and applications}

With advanced data processing as described earlier, lysimeter facilities provide data with proper accuracy (equivalent to $0.1 \mathrm{~mm}$ water height or smaller) and high temporal resolution (hourly or shorter intervals). Based on such datasets, it is possible to quantify both $E T$ and $P$ directly from lysimeter data (e.g., Nolz et al., 2014). The method is based on the assumption that during short time interval either $E T$ (weight losses) or $P$ (weight gains) occurs. The resulting datasets proved more reliable, because it was shown that precipitation amounts on the lysimeter differ from that of separate rain gauge measurements (Gebler et al., 2015; Nolz et al., 2014). While lysimeter data are supposed to represent precipitation that reaches the ground, the discovered differences depend on the type and placement of the respective rain gauge (Hoffmann et al., 2016). With the novel method, dew amounts-representing only a small portion of precipitation in subhumid climatescan also be determined by means of weighing lysimeters (e.g., Nolz et al., 2014). Furthermore, time series for determination of $E T$ contained fewer gaps, whereas in former studies, days with rainfall were often filtered. Hence, this approach represents the state of knowledge of lysimeter data processing.

Adequate datasets of water balance components can thus be used for validation of methods to measure or calculate ET (Allen et al., 2011; Gebler et al., 2015; Groh et al., 2015). Recently, Nolz et al. (2014, 2016a) validated the PM model (Allen et al., 1998) for a subhumid site in the eastern part of Austria. They found that $E T_{\text {ref }}$ calculated with PM was larger than $E T_{\text {ref }}$ measured at a reference grass lysimeter at small values and vice versa. Although the average differences were small over a year, the findings revealed potential of improvement. Hence, Rodný et al. (2016) used data of the same lysimeter to validate a modified method of aerodynamic resistance calculation and its application to potential evapotranspiration estimation. Similar data were also used to evaluate a water balance model for predicting crop water requirements (Muzikova et al., 2010).

In general, applications of sophisticated lysimeter facilities are manifold, including simulations of groundwater fluc- tuations (Fahle and Dietrich, 2014; Dietrich et al., 2016) or validation of water flow models that focus on processes in the vadose zone (Durner et al., 2008; Schelle et al., 2012). An overview on different lysimeter types and their usage was recently presented by Meissner et al. (2014). Beside the large number of lysimeters that were installed during the past few years, older models are also still useful for research. The weighing lysimeters in Bushland, Texas, USA, for example, were installed in the 1980s and up to now were used for studying the soil-plant-atmosphere continuum with regard to sustainable water management (Evett et al., 2016). Related research articles address evapotranspiration, crop coefficients, and irrigation scheduling (e.g., Colaizzi et al., 2014; Evett et al., 2012; Howell et al., 2015); field-scale simulations: model testing and development (e.g., Booker et al., 2014; Colaizzi et al., 2014; Heng et al., 2009); and remote-sensing-based simulations (e.g., Evett et al., 2012; Gowda et al., 2013; Paul et al., 2013).

\section{Soil water sensors}

\subsection{Calibration and performance assessment}

Basic studies of measurement devices help enhancing data quality and thus improving data interpretation with regard to scientific as well as practical questions. Allen (1996), for instance, recommended assessing the integrity of weather data for estimating reference evapotranspiration. In order to obtain precise and reliable measurements, it is essential to know about the capability of a system and its single components. This is important to obtain interpretable results and to avoid drawing wrong conclusions from erroneous data. Beside hardware characteristics (e.g., precision, resolution, and measuring range), it is also essential to have a proper data management. An adequate calibration is also essential, which is why a bulk of literature is available about sensor calibration. Generally, researchers select and arrange measurement systems according to their respective research task. Hence, the performance of a specific setup should also be assessed in this regard. Through all these steps, a certain data quality is crucial. This became particularly demanding in the past years because of the increased installation of large sensors arrays and sensor networks (e.g., Bogena et al., 2010; Terzis et al., 2010).

The requirement of sensor tests shall be illustrated based on two examples: an established soil water content sensor and a novel matric potential sensor. Hydra Probe soil water content sensors (Stevens Water Monitoring Systems, Inc., 
Portland, OR, USA) (Stevens, 2015) are well known from various research applications (e.g., López Riquelme et al., 2009; Smith et al., 2012). Satisfactory literature is available about sensor calibration and performance (e.g., Loiskandl et al., 2010; Seyfried and Murdock, 2004, Seyfried et al., 2005; Vaz et al., 2013). The sensor is known to be robust and the measurements are reliable and precise. However, in spite of soil-specific calibration, the measurement accuracy is $\pm 0.03 \mathrm{~cm}^{3} \cdot \mathrm{cm}^{-3}$, which has to be considered for data interpretation. In contrast to soil water content sensors, which operate from saturation to dryness, matric potential sensors have a limited measuring range. Nolz et al. (2013c) tested novel MPS-1 dielectric sensors (Decagon Devices, Inc., Pullman, WA, USA) in a pressure plate apparatus in the laboratory. The sensors measured matric potential between -10 and $-500 \mathrm{kPa}$, which is a rather large range compared to other sensors. However, because of the very large sensor-to-sensor variation $( \pm 50 \%$ of sensor readings), sensor-specific calibrations turned out to be essential. Using only the factory calibration would result in considerably erroneous data (Malazian et al., 2011; Nolz et al., 2013c). Field tests of MPS-1 in combination with Hydra Probes revealed considerable fluctuations of the readings of both sensor types because of temperature effects (Kammerer et al., 2014). Neglecting such uncertainties when interpreting data might cause wrong scientific conclusions.

\subsection{Applications: Soil water monitoring as basis for irrigation management}

Monitoring soil water status can be valuable for agricultural water management, in particular as basis for demandoriented irrigation control (Acevedo-Opazo et al., 2010; Intrigliolo and Castel, 2004; Thompson et al., 2007). Modern telemetry systems enable the integration of different instruments, for example, soil water and weather sensors, thus providing real-time field data (Kim et al., 2008; Vellidis et al., 2008). Such systems provide an integrated approach, in which different datasets reveal a better overall picture of the respective situation. In general, it should be noted that various combinations and arrangements of sensors might be suitable and feasible depending on the economic and environmental conditions. From a practical and economical point of view, monitoring systems should be as simple as possible. This can be achieved by focusing measurements on the uppermost few decimeters of a soil and using only as few sensors as necessary. In this regard, a key question is whether measuring water status in a cer- tain depth of a soil profile is accurate and representative (Dabach et al., 2015; Soulis et al., 2015). Hence, testing systems under local conditions is recommended regarding an optimal application.

The following case studies exemplify monitoring studies in the eastern part of Austria. The region is characterized by a subhumid climate with a mean annual temperature and precipitation of approximately $10^{\circ} \mathrm{C}$ and $550 \mathrm{~mm}$, respectively. Favorable environmental conditions supported the development of large production areas for various crops in the past decades. However, the region is prone to water-deficit stress and heat stress; hence, irrigation has a long tradition. Moreover, irrigation demand is expected to increase in this region because of the effects of climate change (Nachtnebel et al., 2014). Therefore, proactive water-saving strategies and technologies might help to face predicted future challenges.

A semiautomatic irrigation management system was tested for sprinkler irrigation in maize (Nolz and Cepuder, 2014). A software application collected monitoring data from soil water sensors and weather instruments. Based on these data, an operator set starting and end time of the irrigation system. At the respective time, the application opened and closed valves of the irrigation system. Advantages were that irrigation could be optimized according to the soil water status and weather conditions. Unfortunately, failures of some sprinklers could not be detected, so further tests and optimizations are required. Nolz et al. (2016b) tested a soil water monitoring system in a vineyard with subsurface drip irrigation, which represents the most efficient irrigation method. They proposed a setup of only few soil water sensors in the representative depth of $30 \mathrm{~cm}$. However, local management practices should be considered when installing sensors in the field, as inter-row cropping has an effect on soil water distribution (Nolz et al., 2016c). Nolz et al. (2016b) also presented an approach that does without laborious soil analyses and on-site calibration sensors. A promising potential application of such an approach is to implement specific software into a sensor network in order to control irrigation automatically. This would be a decisive step toward fully automatic irrigation control based on soil water monitoring.

\section{Conclusions and outlook}

Lysimeters and soil water sensors are valuable tools to quantify components of the soil water balance. In com- 
bination with other approaches such as models or remote sensing, measurements provide the basis for agricultural water management. Preconditions to obtain proper datasets are well-maintained equipment and adequate data management. Furthermore, knowledge of system performance is essential for correct data interpretation.

Recent studies focused on improving the processing and interpretation of lysimeter data. A key element in this regard is the smoothing of noisy data. Although some procedures proved helpful, they require subjective decisions of the editor to adapt the degree of smoothing. Future studies should approach this problem by finding procedures that are both objective and reliable and thus suitable for automatized and efficient algorithms. However, enhanced data processing guarantees proper datasets that allow detailed quantification of water balance components. Comparisons of measured and modeled data revealed some deviations that require improvements of the applied models. Especially, some parameters required for calculating reference evapotranspiration should be reviewed under the presented environmental conditions.

Tests of sensors and sensor setups demonstrated the potential of such devices and also revealed some limitations, for example, because of temperature effects. A recurrent and conflicting topic is the adequate site-specific calibration of sensors. On the one hand, it has often proven to be a precondition for proper data interpretation; on the other hand, it is destructive and labor intensive. For these reasons, researchers as well as farmers often apply default calibrations, which are easily available but bear a risk of inaccurate measurements. An Austrian case study referred to these shortcomings with regard to irrigation management. The presented approach considered the optimal arrangement of sensors and the combination of different sensor types in order to enhance data interpretation. Although some methods promise to advance the implementation of sensor technologies, future studies are necessary to validate the findings under different environmental conditions and thus put the results on a broader basis.

\section{References}

Aboukhaled, A., Alfaro, A. and M. Smith (1982): Lysimeters. In: FAO (Ed.): Irrigation and Drainage Paper 39. Food and Agriculture Organization of the United Nations, Rome, Italy.
Acevedo-Opazo, C., Ortaga-Farias, S. and S. Fuentes (2010): Effects of grapevine (Vitis vinifera L.) water status on water consumption, vegetative growth and grape quality: An irrigation scheduling application to achieve regulated deficit irrigation. Agricultural Water Management 97, 956-964.

Albergel, C., de Rosnay, P., Gruhier, C., Munoz-Sabater, J., Hasenauer, S., Isaksen, L., Kerr, Y. and W. Wagner (2012): Evaluation of remotely sensed and modeled soil moisture products using global ground-based in situ observations. Remote Sensing of Environment 118, 215-226.

Allen, R.G. (1996): Assessing integrity of weather data for use in reference evapotranspiration estimation. Journal of Irrigation and Drainage Engineering 122, 97-106.

Allen, R.G., Pereira, L.S., Howell, T.A. and M.E. Jensen (2011): Evapotranspiration information reporting: I. Factors governing measurement accuracy. Agricultural Water Management 98, 899-920.

Allen, R.G., Pereira, L.S., Raes, D. and M. Smith (1998): Crop evapotranspiration: Guidelines for computing crop water requirements. In: FAO (Ed.): Irrigation and drainage paper 56. Food and Agriculture Organization of the United Nations, Rome, Italy.

Aragüés, R., Medina, E.T., Zribi, W., Clavería, I., Álvaro-Fuentes, J. and J. Faci (2015): Soil salinization as a threat to the sustainability of deficit irrigation under present and expected climate change scenarios. Irrigation Science 33, 67-79.

Balykin, D., Puzanov, A., Stephan, E. and R. Meissner (2016): Using the innovative lysimeter technology in the German-Russian research project "KULUNDA". In: Mueller, L., Sheudshen, A.K. and F. Eulenstein (Eds.): Novel methods for monitoring and managing land and water resources in Siberia. Springer International Publishing, Basel, Switzerland, 387-399.

Bocquet-Appel, J.-P. (2011): When the world's population took off: The springboard of the Neolithic demographic transition. Science 333, 560-561.

Bogena, H., Herbst, M., Huisman, J.A., Rosenbaum, U., Weuthen, A. and H. Vereecken (2010): Potential of wireless sensor networks for measuring soil water content variability. Vadose Zone Journal 9, 1002-1013.

Booker, J.D., Lascano, R.J. Evett, S.R. and R.E. Zartman (2014): Evaluation of a landscape-scale approach to cotton modeling. Agronomy Journal 106, 2263-2279.

Colaizzi, P.D., Agam, N., Tolk, J.A., Evett, S.R., Howell, T.A., Gowda, P.H., O'Shaughnessy, S.A., Kustas, W.P. 
and M.C. Anderson (2014): Two source energy balance model to calculate E, T, and ET: Comparison of Priestley-Taylor and Penman-Monteith formulations and two time scaling methods. Transactions of the ASABE 57, 479-498.

Dabach, S., Shani, U. and N. Lazarovitch (2015): Optimal tensiometer placement for high-frequency subsurface drip irrigation management in heterogeneous soils. Agricultural Water Management 152, 91-98.

Dietrich, O., Fahle, M. and M. Seyfarth (2016): Behavior of water balance components at sites with shallow groundwater tables: Possibilities and limitations of their simulation using different ways to control weighable groundwater lysimeters. Agricultural Water Management $163,75-89$.

Durner, W., Jansen, U. and S.C. Iden (2008): Effective hydraulic properties of layered soils at the lysimeter scale determined by inverse modelling. European Journal of Soil Science 59, 114-124.

EUROSTAT (2015): Agriculture, forestry and fishery statistics. Publications Office of the European Union, Luxembourg, 204 pp.

Evett, S.R., Howell, T.A., Schneider, A.D., Copeland, K.S., Dusek, D.A., Brauer, D.K., Tolk, J.A., Marek, G.W., Marek, T.M. and P.H. Gowda (2016): The Bushland lysimeters: A quarter century of crop ET investigations to advance sustainable irrigation. Transactions of the ASABE 59, 163-179.

Evett, S.R., Kustas, W.P., Gowda, P.H., Prueger, J.H. and T.A. Howell (2012): Overview of the Bushland Evapotranspiration and Agricultural Remote sensing EXperiment 2008 (BEAREX08): A field experiment evaluating methods quantifying ET at multiple scales. Advances in Water Resources 50, 4-19.

Fahle, M. and O. Dietrich (2014): Estimation of evapotranspiration using diurnal groundwater level fluctuations: Comparison of different approaches with groundwater lysimeter data. Water Resources Research 5, 273-286.

Garcia-Vila, M. and E. Fereres (2011): Combining the simulation crop model AquaCrop with an economic model for the optimization of irrigation management at farm level. European Journal of Agronomy 36, 21-31.

Gebler, S., Hendricks Franssen, H.-J., Pütz, T., Post, H., Schmidt, M. and H. Vereecken (2015): Actual evapotranspiration and precipitation measured by lysimeters: A comparison with eddy covariance and tipping bucket. Hydrology and Earth System Sciences 19, 2145-2161.
Geerts, S., Raes, D. and M. Garcia (2010): Using AquaCrop to derive deficit irrigation schedules. Agricultural Water Management 98, 213-216.

Gowda, P.H., Howell, T.A., Paul, G., Colaizzi, P.D., Marek, T.H., Su, B. and K.S. Copeland (2013): Deriving hourly evapotranspiration rates with SEBS: A lysimetric evaluation. Vadose Zone Journal, http://dx.doi.org/10.2136/ vzj2012.0110.

Groh, J., Pütz, T., Vanderborght, J. and H. Vereecken (2015): Estimation of evapotranspiration and crop coefficient of an intensively managed grassland ecosystem with lysimeter measurements. 16. Gumpensteiner Lysimetertagung, 107-112.

Guermazi, E., Bouaziz, M. and M. Zairi (2016): Water irrigation management using remote sensing techniques: a case study in Central Tunisia. Environmental Earth Sciences 75, 202.

Hannes, M., Wollschläger, U., Schrader, F., Durner, W., Gebler, S., Pütz, T., Fank, J., von Unold, G. and H.J. Vogel (2015): High-resolution estimation of the water balance components from high-precision lysimeters. Hydrology and Earth System Sciences Discussion 12, 569-608.

Heng, L.K., Hsiao, T.C., Evett, S., Howell, T. and P. Steduto (2009): Validating the FAO AquaCrop model for irrigated and water deficient field maize. Agronomy Journal 101, 488-498.

Hillel, D. (1998): Environmental Soil Physics: Fundamentals, Applications, and Environmental Considerations. Academic Press, New York, USA, 771 pp.

Hoffmann, M., Schwartengräber, R., Wessolek, G. and A. Peters (2016): Comparison of simple rain gauge measurements with precision lysimeter data. Atmospheric Research 174-175, 120-132.

Howell, T.A., Evett, S.R., Tolk, J.A., Copeland, K.S. and T.H. Marek (2015): Evapotranspiration, water productivity and crop coefficients for irrigated sunflower in the U.S. Southern High Plains. Agricultural Water Management 162, 33-46.

Howell, T.A., Schneider, A.D., Dusek, D.A., Marek, T.H. and J.L. Steiner (1995): Calibration and scale performance of Bushland weighing lysimeters. Transactions of the ASAE 38, 1019-1024.

Intrigliolo, D. and J. Castel (2004): Continuous measurement of plant and soil waterstatus for irrigation scheduling in plum. Irrigation Science 23, 93-102.

JCGM (2012): The international vocabulary of metrology - Basic and general concepts and associated terms 
(VIM). $3^{\text {rd }}$ ed., JCGM 200:2012, Joint Committee for Guides in Metrology, 108 pp.

Kastanek, F., Hauer, G. and W. Loiskandl (2002): The concept of virtual lysimeters to measure groundwater recharge and evapotranspiration. In: Singh, V.P., AlRashed, M. and M.M. Sherif (Eds.): Proceedings of the International Conference on Water Resources Management in Arid Regions - Surface Water Hydrology. Vol. 1, Mar 23-27, 2002, Lisse, Kuwait.

Kammerer, G., Nolz, R., Rodny, M. and W. Loiskandl (2014): Performance of Hydra Probe and MPS-1 Soil Water Sensors in Topsoil Tested in Lab and Field. Journal of Water Resource and Protection 6, 1207-1219.

Kim, Y., Evans, R.G. and W.M. Iversen (2008): Remote sensing and control of an irrigation system using a distributed wireless sensor network. IEEE Transactions on Instrumentation and Measurements 57, 1379-1387.

Knappe, S., Haferkorn, U. and R. Meissner (2002): Influence of different agricultural management systems on nitrogen leaching: results of lysimeter studies. Journal of Plant Nutrition and Soil Science 165, 73-77.

Knoblauch, S. and T. Swaton (2007): Erweiterung der Lysimeteranlage Buttelstedt für die Bestimmung von standortabhängigen Schwellenwerten für N-Salden. In: LFZ Raumberg-Gumpenstein (Ed.): Tagungsband der 12. Gumpensteiner Lysimetertagung „Lysimetrie im Konnex zu nationalen und internationalen Regelwerken“. Apr 17-18, 2007, Irdning, Österreich, 35-41.

Loiskandl, W., Buchan, G.D., Sokol, W., Novak, V. and M.L. Himmelbauer (2010): Calibrating Electromagnetic Short Soil Water Sensors. Journal of Hydrology and Hydromechanics 58, 114-125.

Loiskandl, W. and G. Kammerer (2011): Soil Water Management. In: Glinski, J., Horabik, J., and J. Lipiec (Eds.): Encyclopedia of agrophysics. Springer, Berlin.

López Riquelme, J.A., Soto, F., Suardíaz, J., Sánchez, P., Iborra, A. and J.A. Vera (2009): Wireless sensor networks for precision horticulture in southern Spain. Computers and Electronics in Agriculture 68, 25-35.

Malazian, A., Hartsough, P., Kamai, T., Campbell, G., Cobos, D. and J. Hopmans (2011): Evaluation of MPS-1 soil water potential sensor. Journal of Hydrology 402, 126-134.

Malone, R.W., Stewardson, D.J., Bonta, J.V. and T. Nelsen (1999): Calibration and quality control of the Coshocton weighing lysimeters. Transactions of the ASAE 42, 701-712.
Marek, G.W., Evett, S.R., Gowda, P.H., Howell, T.A., Copeland, K.S. and R.L. Baumhardt (2014): Post-processing techniques for reducing errors in weighing lysimeter evapotranspiration (ET) datasets. Transanctions of ASABE 17, 499-515.

Meissner, R., Rupp, H. and M. Seyfarth (2014): Advanced technologies in lysimetry. In: Mueller, L., Saparov, A. and G. Lischeid (Eds.): Novel measurement and assessment tools for monitoring and management of land and water resources in agricultural landscapes of Central Asia. Springer International Publishing, Basel, Switzerland, 159-173.

Monteith, J.L. and M.H. Unsworth (2013): Principles of Environmental Physics: Plants, Animals, and the Atmosphere. $4^{\text {th }}$ ed., Academic Press, New York, 396 pp.

Montoya, F., Camargo, D., Ortega, J.F., Córcoles, J.I. and A. Domínguez (2015): Evaluation of AquaCrop model for a potato crop under different irrigation conditions. Agricultural Water Management 164, 267-280.

Muzikova, B., Chuchma, F., Nolz, R., Stredova, H., Cepuder, P. and M. Stastna (2010): Austrian lysimeter data meeting Czech water balance model - Excerpt of bilateral cooperation. In: Celkova, A. (Ed.): Proceedings of the $18^{\text {th }}$ International Poster Day "Transport of Water, Chemicals and Energy in the Soil-Plant-Atmosphere System". Nov 11, 2010, Bratislava, Slovakia, 372-381.

Nachtnebel, H.P., Dokulil, M., Kuhn, M., Loiskandl, W., Sailer, R. and W. Schöner (2014): Der Einfluss des Klimawandels auf die Hydrosphäre. In: Österreichischer Sachstandsbericht Klimawandel 2014 (AAR14). Austrian Panel on Climate Change (APCC), Verlag der Österreichischen Akademie der Wissenschaften, Wien, Österreich, 411-466.

Nolz, R. and P. Cepuder (2014): Testing a Semi-Automatic Irrigation Management System (SAIMS). In: International Commission on Irrigation and Drainage (ICID) (Ed.): Securing water for food and rural community under climate change. Transactions of the $22^{\text {nd }}$ ICID Congress on Irrigation and Drainage, Vol. 1 - Question 58 and 59, 427 pp.

Nolz, R., Cepuder, P., Balas, J. and W. Loiskandl (2016b): Soil water monitoring in a vineyard and assessment of unsaturated hydraulic parameters as thresholds for irrigation management. Agricultural Water Management 164, 235-242.

Nolz, R., Cepuder, P. and J. Eitzinger (2016a): Comparison of lysimeter based and calculated ASCE reference 
evapotranspiration in a subhumid climate. Theoretical and Applied Climatology 124, 315-324.

Nolz, R., Cepuder, P. and G. Kammerer (2014): Determining soil water-balance components using an irrigated grass lysimeter in NE Austria. Journal of Plant Nutrition and Soil Science 177, 237-244.

Nolz, R., Kammerer, G. and P. Cepuder (2009): Windeinfluss auf die Lysimetermessungen in Groß-Enzersdorf. In: LFZ Raumberg-Gumpenstein (Ed.): Tagungsband der 13. Gumpensteiner Lysimetertagung „Lysimeter Perspektiven in Forschung und Anwendung“. Apr 2122, 2009, Irdning, Österreich, 17-20.

Nolz, R., Kammerer, G. and P. Cepuder (2011): Datenmanagement der wägbaren Lysimeter in Groß-Enzersdorf. In: LFZ Raumberg-Gumpenstein (Ed.): Tagungsband der 14. Gumpensteiner Lysimetertagung "Lysimeter in der Klimaforschung und Wasserwirtschaft". Mai 3-4, 2011, Irdning, Österreich, 33-38.

Nolz, R., Kammerer, G. and P. Cepuder (2013a): Interpretation of lysimeter weighing data affected by wind. Journal of Plant Nutrition and Soil Science 176, 200-208.

Nolz, R., Kammerer, G. and P. Cepuder (2013b): Improving interpretation of lysimeter weighing data. Die Bodenkultur: Journal for Land Management, Food and Environment 64, 27-35.

Nolz, R., Kammerer G. and P. Cepuder (2013c): Calibrating soil water potential sensors integrated into a wireless monitoring network. Agricultural Water Management 116, 12-20.

Nolz, R., Loiskandl, W., Kammerer, G. and M.L. Himmelbauer (2016c): Survey of soil water distribution in a vineyard and implications for subsurface drip irrigation control. Soil and Water Research, doi: 10.17221/170/2015-SWR.

Ochsner, T.E., Cosh, M., Cuenca, R., Dorigo, W., Draper, C., Hagimoto, Y., Kerr, Y.H., Larson K.M., Njoku, E.G., Small, E.E. and M. Zreda (2013): State of the art in large-scale soil moisture monitoring. Soil Science Society of America Journal 77, 1888-1919.

Olesen, J.E. and M. Bindi (2002): Consequences of climate change for European agricultural productivity, land use and policy. European Journal of Agronomy 16, 239-262.

Opdam, J.J.G., Schoonderbeek, G.G., Heller, E.M.B. and A. de Gelder (2005): Closed Greenhouse: a Starting Point for Sustainable Entrepreneurship in Horticulture. In: van Straten, G. and W.Th.M. van Meurs (Eds.): Proceedings of the international conference on sustain- able greenhouse systems. Leuven, Belgium, Sep 12-16, 2004. Acta Horticulturae (ISHS) 691, 517-524.

Paul, G., Gowda, P., Prasad, P., Howell, T.A., Staggenborg, S.A. and C.M. Neale (2013): Lysimetric evaluation of SEBAL using high resolution airborne imagery from BEAREX08. Advances in Water Resources 59, 157168.

Peters, A., Nehls, T., Schonsky, H. and G. Wessolek (2014): Separating precipitation and evapotranspiration from noise - a new filter routine for high-resolution lysimeter data. Hydrology and Earth System Sciences Discussion 18, 1189-1198.

Prasuhn, V., Spiess, E. and M. Seyfarth (2009): Die neue Lysimeteranlage Zürich-Reckenholz. In: LFZ Raumberg-Gumpenstein (Ed.): Tagungsband der 13. Gumpensteiner Lysimetertagung „Lysimeter - Perspektiven in Forschung und Anwendung". Apr 21-22, 2009, Irdning, Österreich, 11-16.

Rodný, M., Nolz, R., Novák, V., Hlaváčiková, H., Loiskandl, W. and M.L. Himmelbauer (2016): Modified method of aerodynamic resistance calculation and its application to potential evapotranspiration estimation. International Agrophysics 30, 231-235.

Schelle, H., Iden, S.C., Fank, J. and W. Durner (2012): Inverse estimation of soil hydraulic and root distribution parameters from lysimeter data. Vadose Zone Journal 11, doi: 10.2136/vzj2011.0169.

Schrader, F., Durner, W., Fank, J., Gebler, S., Pütz, T., Hannes, M. and U. Wollschläger (2013): Estimating precipitation and actual evapotranspiration from precision lysimeter measurements. Procedia Environmental Sciences 19, 543-552.

Smith, A.B., Walker, J.P., Western, A.W., Young, R.I., Ellett, K.M., Pipunic, R.C., Grayson, R.B., Siriwidena, L., Chiew, F.H.S. and H. Richter (2012): The Murrumbidgee soil moisture monitoring network data set. Water Resources Research 48, W07701.

Stevens (2015): Comprehensive Stevens Hydra Probe Users Manual, Rev. IV. Stevens Water Monitoring Systems Inc., Portland.

Seyfried, M.S., Grant, L.E., Du, E. and K. Humes (2005): Dielectric loss and calibration of the Hydra Probe soil water sensor. Vadose Zone Journal 4, 1070-1079.

Seyfried, M.S. and M.D. Murdock (2004): Measurement of soil water content with a $50-\mathrm{MHz}$ soil dielectric sensor. Soil Science Society of America Journal 68, 394-403. 
Soulis, K.X., Elmaloglou, S. and N. Dercas (2015): Investigating the effects of soil moisture sensors positioning and accuracy on soil moisture based drip irrigation scheduling systems. Agricultural Water Management 148, 258-268.

Terzis, A., Musaloiu-E, R., Cogan, J., Szlavecz, K., Szalay, A., Gray, J., Ozer, S., Liang, C.J.M., Gupchup, J. and R. Burns (2010): Wireless sensor networks for soil science. International Journal of Sensor Networks 7, 53-70.

Thompson, R.B., Gallardo, M., Valdez, L.C. and M.D. Fernandez (2007): Determination of lower limits for irrigation management using in situ assessments of apparent crop water uptake made with volumetric soil water content sensors. Agricultural Water Management 92, 13-28.

Toureiro, C., Serralheiro, R., Shahidian, S. and A. Sousa (2016): Irrigation management with remote sensing: Evaluating irrigation requirement for maize under Mediterranean climate condition. Agricultural Water Management. doi:10.1016/j.agwat.2016.02.010.

Vaughan, P.J. and J.E. Ayars (2009): Noise reduction methods for weighing lysimeters. Journal of Irrigation and Drainage Engineering 135, 235-240.

Vaz, C.M.P., Jones, S., Meding, M. and M. Tuller (2013): Evaluation of standard calibration functions for eight electromagnetic soil moisture sensors. Vadose Zone Journal 12. doi.org/10.2136/vzj2012.0160.
Vellidis, G., Tucker, M., Perry, C., Wen, C. and C. Bednarz (2008): A real-time wireless smart sensor array for scheduling irrigation. Computers and Electronics in Agriculture 61, 44-50.

von Unold, G. and J. Fank (2008): Modular design of field lysimeters for specific application needs. Water Air and Soil Pollution: Focus 8, 233-242.

Wegehenkel, M., Zhang, Y., Zenker, T. and H. Diestel (2008): The use of lysimeter data for the test of two soil-water balance models: A case study. Journal of Plant Nutrition and Soil Science 171, 762-776.

Zacharias, S., Bogena, H., Samaniego, L., Mauder, M., Fuss, R., Pütz, T., Frenzel, M., Schwank, M., Baessler, C., Butterbach-Bahl, K., Bens, O., Borg, E., Brauer, A., Dietrich, P., Hajnsek, I., Helle, G., Kiese, R., Kunstmann, H., Klotz, S., Munch, J.C., Papen, H., Priesack, E., Schmid, H.P., Steinbrecher, R., Rosenbaum, U., Teutsch, G. and H. Vereecken (2011): A network of terrestrial environmental observatories in Germany. Vadose Zone Journal 10, 955-973.

Zhang, Y. and M. Wegehenkel (2006): Integration of MODIS data into a simple model for the spatial distributed simulation of soil water content and evapotranspiration. Remote Sensing of Environment 104, 393-408. 